Revista de
Economild
Contemporâned

\title{
NATIONAL SYSTEM OF INNOVATION: A NOTE ON TECHNOLOGICAL ASYMMETRIES AND CATCHING-UP PERSPECTIVES
}

\author{
Mario Cimoli ${ }^{a}$ \\ ${ }^{a}$ ECLAC-UN and Department of Economics, University of Venice “Ca’Foscari”.
}

Manuscript received on 2/2/2014 and approved on 3/30/2014.

\begin{abstract}
What distinguishes the National Innovation System (NIS) across different countries? Could the NIS be considered a useful analytical framework to explain growth performances? Which kind of representation can supersede the "push policy view" of NIS approach? These questions are worthy of particular attention for the understanding of potential empirical and analytical achievements of this approach. This paper discusses the main approaches that explain technological divergence and convergence. It is argued that another element identified as the "national institutional dimension" has to be explicitly taken into account for the understanding of the interplay that exists between technology, specialization and growth. It also provides a macro-representation of NIS which potentially captures and identifies at the micro, meso and macro levels the main threads that link innovation, institutions, competencies and economic performances, as well as a simple graphical model of the interplay between NIS, competencies and growth performances.
\end{abstract}

KEYWORDS: National Innovation System; technology; competencies; specialization; growth.

JEL CODES: O3; O4; O5.

Correspondence to Mario Cimoli.

E-mail: mario.cimoli@cepal.org. 


\section{SISTEMA NACIONAL DE INOVAÇÃO: NOTAS SOBRE ASSIMETRIAS TECNOLOGICAS E PERSPECTIVAS DE CATCHING-UP}

RESUMO: O que diferencia o Sistema Nacional de Inovação (SNI) de cada país? O SNI pode ser considerado um modelo analítico útil para explicar as performances econômicas? Que tipo de representação pode suceder a "visão da política de indução" característica da abordagem do SNI? Tais questões são particularmente importantes para o entendimento dos possíveis resultados empíricos e analíticos dessa abordagem. Este trabalho discute as principais abordagens que explicam a convergência e a divergência tecnológica. Argumenta-se que outro elemento identificado como a "dimensão institucional nacional" deve ser explicitamente levado em consideração para o entendimento das interrelações entre tecnologia, especialização e crescimento. Este trabalho também propõe uma macro-representação do SNI que potencialmente captura e identifica os níveis micro, meso e macro dos principais eixos que relacionam inovação, instituições, competências e performance econômica, além de fornecer um modelo gráfico simplificado sobre as relações entre o SNI, as competências e o crescimento econômico.

PALAVRAS-CHAVE: Sistema Nacional de Inovação; tecnologia; competências; especialização; crescimento. 


\section{INTRODUCTION}

What distinguishes the National Innovation System (NIS) across different countries? Could the NIS be considered a useful analytical framework to explain growth performances? Which kind of representation can supersede the "push policy view" of NIS approach? These questions are worthy of particular attention for the understanding of empirical and analytical potential achievements of this approach.

First, I shall provide a summary view of the neo-Schumpeterian approach and its main contributions to the understanding of technology as an important source for growth. In doing so, this approach introduces technological asymmetries between countries as a crucial aspect to explain trade, specialization, forging ahead, catching-up and falling behind.

Second, I shall suggest the hypothesis that the NIS could be considered as a useful proxy of institutional differences and support the idea of the increasing importance of "created assets" in the explanation of growth and specialization performances. The importance of the institutional dimension should come unsurprisingly, supported by growing evidence from both micro and macro patterns of technological change. After all, at the micro level, technologies are to a fair extent incorporated into particular institutions, the firms, whose characteristics, decision rules, capabilities, and behavior are fundamental to shaping the rates and directions of technological advance. However, although the NIS concept can be useful to capture differences across countries, a schematic representation of the NIS and its interplay with the economic performances will be introduced explicitly based on a longer essay by Cimoli and Della Giusta (1997). This macro-representation will allow for a comparative analysis of the "goodness" or "badness" of the NIS in terms of the main implication for specialization and economic performances, as different scenarios characterized by catching-up, falling-behind and forging ahead perspectives.

Third, throughout this discussion it will be pinpointed that the interplay between the NIS and performances is not linear and a deterministic conclusion cannot be drawn. It will be particularly stressed that the nature of the interplay between the NIS and economic performances is also shaped, among others, by the historical events related to industries and technological strategies, the specialization pattern, the constraints imposed by trade balance conditions and policies related to the macroeconomic setting and exchange rate stabilization.

In the first section a discussion of the main approaches that explain technological divergence and convergence will be presented. In this context, it will be emphasized that another element identified as the "national institutional dimension" has to be explicitly taken into account for the understanding of the interplay that exists between technology, specialization and growth. Section two is devoted to a macro-representation of the 
NIS which potentially captures and identifies at the micro, meso and macro levels the main threads that link innovation, institutions, competencies and economic performances. Section three contains a simple graphical model of the interplay between the NIS, competencies and growth performances. In section four a brief conclusion is included.

\section{ASYMMETRIES IN TECHNOLOGY AND GROWTH}

Since the 1960's, the central purpose of most contributions in the field of technology and trade has been to highlight the crucial importance of technological change and innovation in explaining the international trade pattern, e.g. Posner (1961), Freeman (1963), Hirsch (1965), Hufbauer (1966) and Vernon (1966). This approach has stressed international asymmetries in technology as the main determinant of trade flows and specialization patterns ${ }^{1}$.

In Posner (1961), the initial asymmetric access to technological knowledge in a world characterized by similarities in demand patterns explains the pattern of trade. In this context, trade between countries will be maintained if differences in national abilities to innovate and imitate persist. After a lapse of time, most countries can imitate the new commodity and restore technological parity, also eliminating the basis for trade. Freeman (1963) and Hufbauer (1966) have stressed the differences in the factors which determine specialization before and after the imitation process takes place. Thus, during the innovation process the effects of patents, commercial secrecy, static and dynamic economies of scale prevail. However, once imitation occurs, specialization will be determined by the traditional process of adjustment in production cost and competitiveness.

In Hirsch (1965) and Vernon (1966), technological asymmetries are associated to distinct phases in the evolution of a technology and a specific international distribution of innovative capabilities in the production of new commodities. Innovative advantage is the main feature of the initial phase, explaining the production of new commodities in the advanced countries. Over time, technology evolves into a mature phase, characterized by the standardization of products and processes. In this latter phase, international competition is based on production cost advantages and technology can be transferred to less developed economies, whose comparative advantage lies in their lower real wages. In this respect, the pattern of trade is considered a pro-

1 In these approaches, technology is considered as a good that is not free, which provides an important advantage to the first innovator country. 
cess of technological divergence and convergence, in which the innovative process induces divergence while imitation and diffusion induce convergence between countries $^{2}$.

In doing so, many of these studies have undoubtedly scored points with policy makers who have increasingly come to recognize the significance of technology for international competitiveness. The theoretical basis of these contributions remains, however, poor. This is in fact not surprising. The introduction of "technology" in any kind of trade model, whether of the classical or the neo-classical sort, raises many challenges. The complexity of the phenomenon of technological change on the one hand (with its dual impact on efficiency and new demand) and the essential dynamic "change" perspective implicit in the concept of technological change, on the other, are difficult to handle in their completeness in any kind of economic model.

The recent evolutionary formal approach puts increasing attention into uneven international technological change as an engine of growth with emphasis on the dynamics of specialization as in Metcalfe (1989), Metcalfe and Soete (1984), Amable (1992, 1993), Boggio (1993) and Soete and Verspagen (1992), and on the dynamics of catching-up as analyzed in Verspagen (1990, 1991), Dosi and Freeman (1992) and Fagerberg (1995a).

In this context, the formal approach developed in Dosi and Soete (1983), Dosi, Pavitt and Soete (1990), Cimoli (1988), Cimoli and Soete (1992), Canter and Hanusch (1990) has pinpointed the importance of the interplay between absolute and comparative advantages as determinants of the participation of each country in world trade, the dominance of technological gaps in the process of international specialization, and the bounds imposed by the dynamics of innovation and trade on the "growth possibility sets" of each economy. On the determinants of absolute and comparative advantages, technological gaps - in terms of product and process innovation - and institutional asymmetries - in terms of the main form of organization of labour markets - contribute to determining the pattern of specialization and its evolution over time. On the demand side, on the other hand, asymmetries in national consumption patterns, regarding price and income elasticities, play a crucial role on the interplay between specialization and the macroeconomic level of activity. Finally, the trade balance condition determines the growth rate differential of trading economies ${ }^{3}$.

\footnotetext{
2 A variety of models which capture the dynamics of specialization in term of substituting process between new and standard (old) commodities has been recently introduced; among others, see Krugman (1987) and Dollar (1986).

3 The main characteristics of this approach can be viewed not only in terms of modelling methodologies, but also in the ways in which some of the empirical properties of the world economy are considered. Thus, the structuralist/evolutionary approach has tried to account for what can be reasonably conside-
} 
This approach has demonstrated that the growth of relative trading partners depends not only on the demand structure of each economy constrained by the conditions of the balance of payments, but also, particularly, on differences in technology. Furthermore, the technological gap is introduced as one of the main variables explaining the pattern of growth possibilities by means of the effect of what we will refer to here as the technological gap multiplier which accounts for the initial distance between countries in terms of technological capabilities.

Wide differences apply to the capabilities of developing new products and to different time lags in producing them after they have been introduced into the world economy. Indeed, the international distribution of innovative capabilities regarding new products is at least as uneven as that regarding production processes. For example, if one takes international patents or the number of discrete innovations as a proxy for innovativeness, the evidence suggests that the club of innovators has been restricted over the whole past century to a dozen developed countries with only one major new entry, Japan. Second, the process of development and industrialization are strictly linked to the inter- and intra-national diffusion of "superior" techniques. Accordingly, as already mentioned, at any point in time, there is likely to be only one or, at most, very few "best practice" techniques of production which correspond to the technological frontier. In the case of developing economies, the process of industrialization is thus closely linked to the borrowing, imitation and adaptation of established technologies from more advanced economies. These processes of adoption and adaptation of technologies, in turn, are influenced by the specific capabilities of each economy.

\section{NIS-COMPETENCIES AND ECONOMIC PERFORMANCES}

Government intervention in the Latin American and the Pacific Rim newly industrialized economies (NIE) played an essential role in industrialization, but with opposite orientations with respect to market orientation and specialization. The Latin American NIE have been characterized by production for domestic markets, whereas the Southeast Asian ones by export orientation and specialization in manufactured commodities. In the latter group of economies, a particular emphasis has been put into the promotion of linkages

red as some fundamental properties affecting the interplay between trade and growth: a) the different commodities show a wide range of price and income elasticities; b) the rate of growth of each economy is normally constrained by the need to balance the foreign account; $c$ ) wage rates are mainly determined by institutional factors which account for the mechanism that relates wage and productivity over time; and d) the interplay between technical change, trade, and growth has to be interpreted as a mechanism that generates a tendency to converge to an equilibrium in the world rate of growth only as a particular case. 
across enterprises, often with the involvement of multinational enterprises (MNE) subsidiaries, with the scope of promoting a stable access to technology transfer and a fruitful mode of diffusion into the whole economy. Another essential aspect in the development of these countries has been that of human capital formation; the role in industrial development of the scientific and educational system, in particular, has been repeatedly underlined in the literature on the Asian NIE, where it has been often indicated as a fundamental precondition to their success. On the whole, the general pattern of incentives defined by the existing institutions has accounted for the type of response to internal and external stimuli which have determined the relative success, and failure, of the NIE.

There is a significant body of literature explaining the importance of institutions and their role in economic and industrial development. In particular, regarding the Pacific Rim NIE, the works by Amsden (1989), Wade (1990), Cantwell (1991) and many others help understand not only how institutional success can exist, but also how institutional failure can too. Bardhan (1996) analyzes such issue as one of co-ordination, which has to be seen in terms of the interaction of distributive conflicts with state capacity and governance structure. The author suggests that the success of institutions in some NIE (namely South Korea and Taiwan) has to be understood in terms of the capacity of establishing and applying rules of performance criteria, so that, for example, credit allocation by the state was tightly bound with export performance; in this way, international competition was used to foster internal learning. Most of these approaches point out that growth is not automatic. Growth needs of a "social capability" which can be viewed as a

[...] rubric that covers countries' levels of general education and technical competence, the commercial, industrial and financial institutions that bear on their ability to finance and operate modern, large-scale business, and the political and social characteristics that influence the risks, the incentives and the personal rewards of economic activity including those rewards in social esteem that go beyond money and wealth. (Abramovitz, 1994)

These patterns provide examples of the functioning of what could be understood as a NIS ${ }^{4}$. Within this context, a variety of overlapped NIS concepts, with different emphasis at the firms, meso and macroeconomic levels, have been recently introduced (Edquist, 1997). Think to the concepts introduced in Freeman (1987) and Nelson (1993), here within the national boundaries the attention is given to the analysis of a set of actors firms and, particularly, other institutions such as universities, research organizations, etc 4 Abramovitz's notion of differentiated "social capabilities" is quite consistent with this view (Abramovitz,
1989). 
- and the links between them in the innovation and diffusion processes. Metcalfe (1995) provides a policy-oriented definition of National Innovation System as a "set of institutions which jointly and individually contribute to the development and diffusion of new technologies and which provides the framework within which governments form and implement policies to influence the innovation process". He argues that the nature of each NIS is fundamentally shaped by both the division of labor and the peculiarities of information, which cause a predominance of co-ordination by non-market means. The institutions that compose them (private firms, universities and other educational institutions, public research labs, private consultancies, professional societies, industrial research associations) "make complementary contributions but they differ significantly with respect to motivation and to a commitment to dissemination of the knowledge they create" (ibidem). A more recent analysis referring specifically at the NIS approach in the NIE can be found in the works by Katz (1997), Kim (1997) and Lall (1997). The argument here put the emphasis on the "message" that growth and catching-up potentiality are clearly related to country historical paths and development of a local NIS. Institutions, industrial and Science \&Technology policies - as those that support science, human capital, competencies and learning capabilities - are the main variables introduced to explain differences between the NIS developed in both Latin American and Asian NIE.

The evolutionary foundations which account for the characteristics of national systems of production and innovation develop through to the ideas that firms are repositories of knowledge, that they are nested in networks of linkages with other firms and also with other non-profit organizations (networks which enhance the opportunities facing each firm to improve their problem-solving capabilities), and finally that there exists a broader notion (at a wider level of aggregation) of embeddedness of microeconomic behaviors into a set of social relationships, rules and political constraints (Granovetter, 1985).

Even at a properly micro level, the momentum associated with single technological trajectories is itself a largely social concept: "it points to the organizations and people committed by various interests to the system, to manufacturing corporations, research and development laboratories, investment banking houses, educational institutions and regulatory bodies" (Misa, 1991, p. 15). And, in turn, these interests and institutions are sustained by the increasing return and local nature of most learning activities. Even more so, at a system level, the interpretation presented here is consistent, and indeed complementary, with institutional approaches building on the observation that markets do not exist nor operate apart from the rules and institutions that establish them and that "the institutional structure of the economy creates a distinct pattern of constraints and incentives", which defines the interests of the actors as well as shaping and channeling their behaviors (Zysman, 1994, p. 1-2).

Nations are characterized by particular modes of institutional governance which to a certain extent make them diverse auto reproducing entities. Moreover, there exist 
an element of nationality which is provided by the shared language and culture, and by the national focus of other policies, laws and regulations which condition the innovative environment (Metcalfe, 1995). Together, they contribute to shape the organizational and technological context within which each economic activity takes place. In a sense, they set the opportunities and constraints each individual process of production and innovation faces - including the availability of complementary skills, information on intermediate inputs and capital goods, and demand stimuli to improve particular products. Institutional and technological diversities are seen in this context as the true determinants of development. The processes described here are in fact inherently co-evolutionary (Nelson, 1992) in nature and therefore characterized by constant feedback mechanisms. Such feedbacks take place essentially between performance and competency, but the role of the institutional strategies remains essential in the process.

In this section, I shall propose a concept and a representation of the NIS which empirically capture the main features that explain the technological asymmetries introduced above and some pieces of the case studies on the NIS. Moreover, by means of the systematization of this representation, two different attempts will be pursued. On the one hand, the major task of this interpretation will be the identification of an aggregate structure where the main threads that link technology, institutions, competencies and economic performances may be placed and described. On the other hand, an implication of this view is related to a broader set of approaches that look for a framework where the mechanism that supports technical change and innovation could be understood, so that governments could form and implement policies in order to influence the innovation process (Cimoli and Della Giusta, 1997).

In order to put together the components regarding the asymmetries in technology that have been developed so far, and therefore with a view to take a further step in the understanding of the process of technological change at institutional levels, I now propose the idea of a set of technological capabilities (evolving in both time and space), defined by competence (that essentially refers to a firm's, organization's and country's abilities to solve both technical and organizational problems) on the one side, and by performance (as measured by variables such as competitiveness, and contribution to industrial growth) on the other. In between those two entities, and shaping their interaction (and therefore causing the magnitude of the span that exists between the two) there lies the national innovation system, acting at both the national and regional levels and therefore possessing an inherently local nature (see Figure 1$)^{5}$.

5 Other definition of national technological capabilities that captures the main features of learning and institutional setting is associated to a "[...] complex of skills, experience and conscious effort that enables 


\section{Figure 1 - A point in the set of technological capabilities defining the state of an economic system}

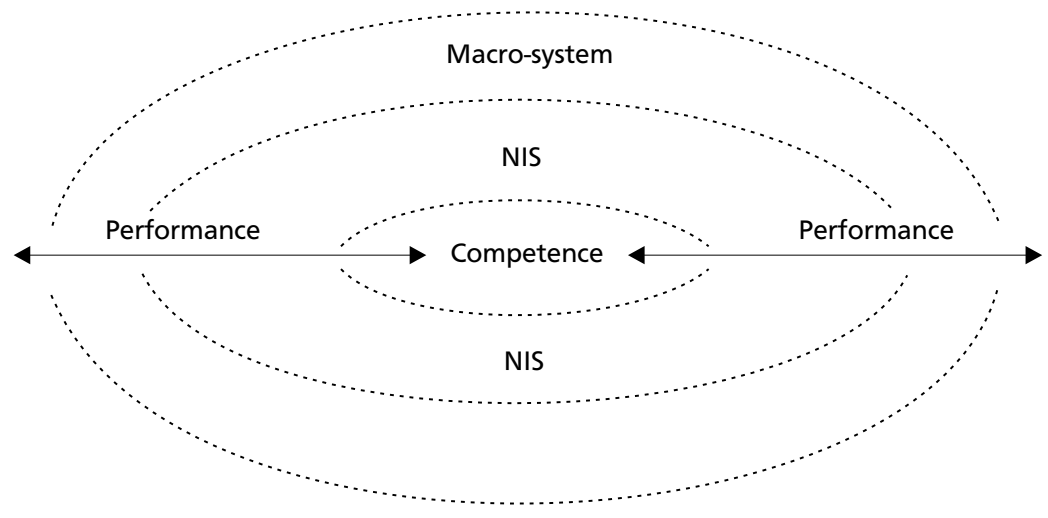

Source: Cimoli and Della Giusta (1997).

The hypothesis here is that differences in technological capabilities are a fruitful starting point for a theory that shows how technological gaps and national institutional diversities can jointly reproduce themselves over rather long spans of time in ways that are easily compatible with the patterns of incentives and opportunities facing individual agents, even when they turn out to be profoundly suboptimal from a collective point of view. Conversely, in other circumstances, it might be precisely this institutional and technological diversity among countries which may foster catching up (and, rarely leapfrogging) in innovative capabilities and per capita incomes. Rigorous demonstrations of these propositions would indeed require many intermediate steps, linking externalities and positive feedback mechanisms based on technological learning with the institutional context in which microeconomic agents are embedded, and also the economic signals they face. Here let us just emphasize that systematically different rates of learning might have very little to do with "how well markets work". Rather, incentives and opportunities which agents perceive in a particular context are themselves the result of particular histories of technologies and institutions.

a country's enterprises to efficiently buy, use, adapt and improve and create technologies. The individual enterprise is the fundamental unit of technological activity, but national capability is larger than the sum of individual firm capability. It comprises the non-market system of linkages, business culture and institutions that enable firms to interact with each other, exchanging the information needed to co-ordinate their activities and to undertake what effectively amounts to collective learning" (Lall, 1997). 
Figure 2 - A simple representation of the interaction between competence and NIS

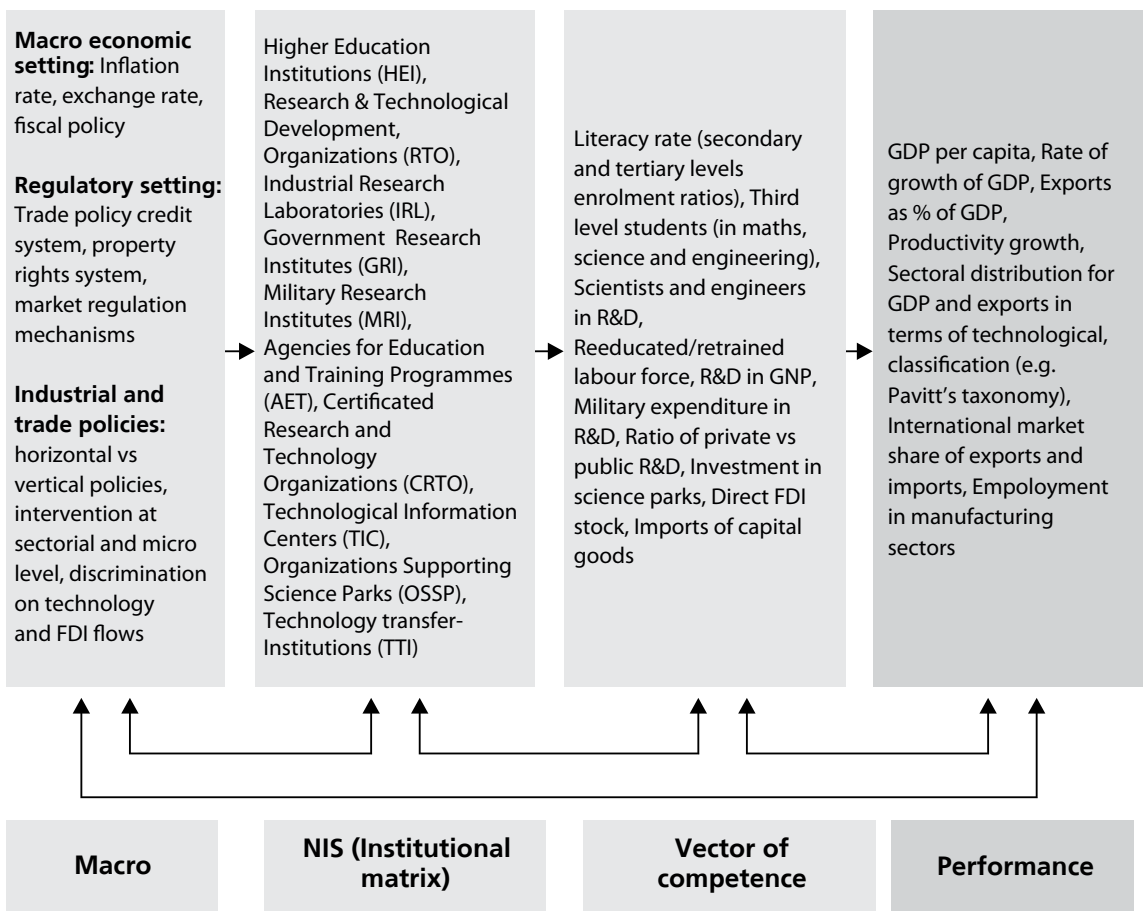

Source: Author's elaboration.

Moreover, by systematizing the difference between competence and performance, it could also become possible to create a concept of measurement of the "goodness" or "badness" of the NIS. The representation introduced above makes it possible to explain why technological gaps among countries reproduce themselves over time due to the fact that individual behaviors (in response to the existing patterns of incentives and opportunities) produce suboptimal collective outcomes. In other words, the existence of diverse institutions and organizations and their modes of interaction determine specific national systems of innovation which over time present certain invariant characteristics which account for their phases of relative "technological success and failure" (Cimoli and Dosi, 1995). When organized appropriately, NIS are a powerful engine of progress; poorly organized and connected they may seriously inhibit the process of innovation (Metcalfe, 1995) ${ }^{6}$.

6 There also exists an international dimension given by MNE strategies that provokes slipover effects of technology policies of one nation on those of the others. Increasing mobility of firms' resources (FDI, 
In providing this tentative representation of the processes described above, we are aware of the oversimplification entailed by the implicit assumption that we are making; namely, that the vector of competencies and the matrix of NIS must be of compatible dimensions (i.e. to each component of competence should correspond a component of the NIS), and that there still exists the problem of defining and measuring such components. The latter, furthermore, is complicated by the presence of all those informal types of relationships between organizations and institutions (and among both sets of actors) that in standard literature fall under the heading of "externalities". Clearly, further investigation will be required in order to provide a more solid base to this representation of our structure. Nonetheless, we believe that the structure would provide a help in the understanding of the mechanisms by which the NIS determine the success and failure of technological progress, and therefore the positioning of the set of technological capabilities.

At a system level, there exist some macro-level indicators of policy that, in our opinion, have to be viewed as both conditioning elements and results of the system's performance (macro economic and regulatory settings, industrial and trade policies).

The matrix of the NIS is akin to the concept of "institutional matrix which supports and sustains the activities of innovating firms" proposed by Metcalfe (1995), and although the representation is linear, one must keep in mind that this is so only for the sake of representation. In this framework, the possibility of institutional failures becomes incorporated into a broad structure which is able to account for the interactions among the main agents in the process of development. The essential feature of this system is constituted by the interface between capabilities and performance and the role that the NIS plays in it as the wider representative of institutions (both public and private). Knowledge flows are embodied into individuals and their organizations, as stated before, and therefore it is obvious that the central part in the system is played by a collection of institutions. Most countries are characterized by different type of institutions which however could be distinguished according to how they contribute to the development of technologies and the role that they play in the whole system. Thus, one can think at the following institutions as a sort of representative sample of those actually existing in different countries: higher education institutions (HEI), research \& technological development organizations (RTO), industrial research laboratories (IRL),

\footnotetext{
strategic alliances, and so forth) and the globalization of the world economy can modify the main elements that explain the origin and the orientation of the NIS-competence, in terms of whether it is biased in favor of the MNE's strategy or mainly determined by the country's scientific and technology policy. On the other hand, the national unit is too large to understand the effects of the innovative process in a particular area: it becomes therefore important to focus on the appropriate unit of analysis, and therefore on distinct systems geographically and institutionally localized.
} 
government research institutes (GRI), military research institutes (MRI), agencies for education and training programmes (AET), certificated research and technology organizations (CRTO), technological information centers (TIC), organizations supporting science parks (OSSP), technology transfer-institutions (TTI).

At a national level, competencies are clearly very difficult to be estimated and quantified. Thus, the country's efforts to create these could be considered as proxies of the main competencies available in each economy ${ }^{7}$. Competencies can be identified as those which pertain to the following groups: educational (literacy rate, secondary and tertiary level enrolment ratios, third level students in math, science and engineering), $R \& D$ efforts (scientists and engineers in $R \& D, R \& D$ in GNP, ratio of private and public $R \& D$ ), technology transfer efforts (direct FDI stock, imports of capital goods). An essential aspect of competencies regards its interplay with the catching up argument. In particular, when a country behind the world innovation frontier is considered, most of the competencies variables could be considered as a support for the scope for imitation. Thus, by means of the representation introduced before catching-up processes based on borrowing, imitation and adaptation of established technologies from more advanced countries can be captured (Gomulka, 1971; Abramovitz, 1989; Maddison, 1991; Fagerberg, 1995a).

Economic performances depend on how each country implement policies (to stabilize the macroeconomic setting, to promote the industrial sectors) and organize its institutional matrix and competencies. The relevant variables which can be considered as a proxy for the scope of catching-up are: GDP per capita, rate of growth of GDP, exports as a percentage of GDP, productivity growth, technological sectoral distribution for GDP and exports in terms technological classification (Pavitt's taxonomy or others), international market share of exports and imports and employment in manufacturing sectors.

\section{THE NIS: CONSEQUENCES FOR FORGING AHEAD, CATCHING-UP AND FALLING BEHIND}

By referring to the trade and growth analysis introduced before it is possible to draw an interpretation and a representation of the main interplay between the NIS and growth performances ${ }^{8}$.

\footnotetext{
"Competencies" here are used in a specific sense that captures those that are developed in the industrial sector (firms, institutions etc), incorporated in the human capital and specific institution dedicated to support innovative activities. The definition used here includes only the efforts addressed to innovative activities, while performances, in terms of export activities and growth, are viewed as the outcome of the above representation.

8 The graphical model presented in this section has been adapted from Dosi, Pavitt and Soete (1990) and Cimoli (1994).
} 
Within the learning economics, the mechanisms of adoption and learning substantially modify - and add new interpretations to - the cost functions faced by the sectoral country productivity. The description of the process proposed here explains how unit costs decrease in accordance to a technologically determined learning curve, with competencies clearly possessing a cumulative character ${ }^{9}$. This process has been adapted in the evolutionary-structuralist models which introduced some sort of Verdoorn-Kaldor law for the explanation of the interplay between learning, dynamics of productivity and trade specialization ${ }^{10}$. The introduction of increasing returns in endogenous dynamics is displayed by a mechanism where explanation gains in specialization in terms of an increase in exports and higher international market shares ${ }^{11}$.

In Figure 3, we provide a representation of the interplay that exists between productivity $(\pi)$ and exports $(z)^{12}$, where each schedule $\pi-z$ shows that changes in produc-

9 It is extremely interesting to note how the existence of increasing returns to adoption is equally explained by the micro-level process (Dosi, 1984).

${ }_{10}$ A paradigm-based theory of innovation and production seems to be highly consistent with the evidence on the patterned and cumulative nature of technical change and also with the evidence on microeconomic heterogeneity and technological gaps. Moreover, it directly links to those theories of production which allow for dynamic increasing returns from A. Young and Kaldor to the recent and more rigorous formalizations of path-dependent models of innovation diffusion, whereby the interaction between micro decisions and some form of learning or some externalities produces irreversible technological paths and lock-in effects with respect to technologies which may well be inferior, on any welfare measure, to other national ones, but still happen to be dominant - loosely speaking- because of the weight of their history (cf. the models by B. Arthur and P. David). However, paradigms are generally embodied in larger technological systems and in even larger economic-wide systems of production and innovation. These evolutionary characteristics of the technical change process are seen in a complementary perspective as responsible for the occurrence of what has been called "lock-in by historical events" (Arthur, 1989). This suggests a view of the process of selection and adoption of technologies dominated by path-dependency, unpredictability, inflexibility (the more widespread the adoption of a particular technology is, the fewer the chances of another of being adopted are) and possible selection of inferior technologies (an example of the latter is the adoption of light-water reactors instead of gas-cooled reactors, which are now considered inferior). For example, Genthon (1995) discusses at length the failure of piecemeal national champion European policies, a failure that presents some sort of similarity with the dramatic failure of such major attempts to build an independent computer industry as those of Brazil and India at the dawn of the personal computing era (Delapierre and Zimmermann, 1986; Gaio, 1990). Several implications are derived from this (those concerning the catching-up by developing countries are especially interesting), among which the fact that the history of a firm (in terms of the techniques it is and was able to master), sector and institutions are very important in determining its current choices of technique and that phenomena of path-dependency and lock-in by historical events would emerge.

${ }_{11}$ All this is to reconsider dynamic comparative advantages as a useful principle for the explanation of trade performance and, particularly, a dynamics comparative advantages principle based mainly on "learning dynamics" and not exclusively on the differences in terms of "natural" assets (oil, coffee, labor, etc) and "created" ones (NIS-competences).

${ }^{12}$ In this respect, $\pi$ is considered as the average labor productivity in the industrial sectors. However, this analysis could be extended to a reconsideration of capital inputs, see Dosi, Pavitt and Soete (1990). 
tivity are leaded by exports increasing. Thus, under the assumptions that a change in productivity will affect the whole range of commodities produced ${ }^{13}$, an increase in the country's exports - higher participation in the world economy and market shares for the commodities already exported - will lead to a higher productivity via learning mechanisms, organizational change and quality improvements ${ }^{14}$.

Figure 3 - NIS-competencies and specialization

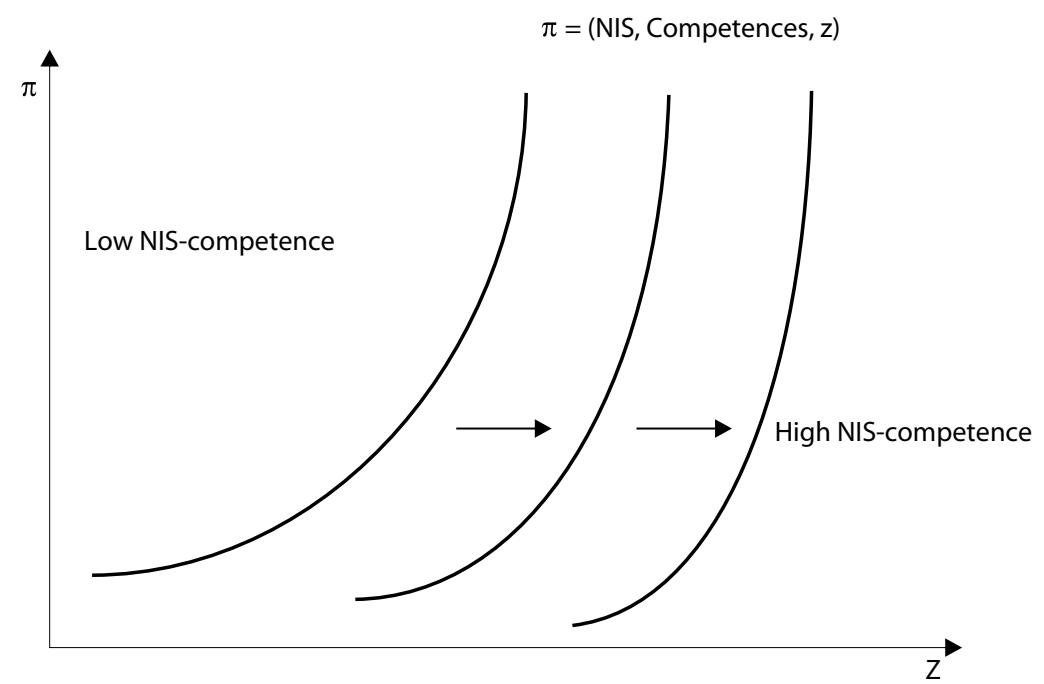

Source: Author's elaboration based on Cimoli, Dosi and Soete (1986) and Krugman (1987).

By referring to these relationships different schedules of specialization and productivity can be obtained. In Figure 3, an increase in domestic competencies - literacy rate, secondary and tertiary level enrolment ratios, third level students in math, science and engineering, scientists and engineers in $R \& D, R \& D$ in GNP (private and public $R \& D$ ), direct FDI stock, imports of capital goods, etc - moves the function to the right side and will increase the number and type of commodities exported. In the high NIS-competencies area, the number of commodities produced and exported will be increased (new international markets could be gained for "new" commodities that have been already imported or produced only for the local market). Two simple and schematic

${ }^{13}$ In this case that a similar consumption pattern prevails and production costs are given and fixed in both economies.

14 This figure is obtained from a model with a continuum of goods where the dynamic increasing returns are introduced, as in Cimoli, Dosi and Soete (1986) and Krugman (1987). 
processes are here described. First, a country can obtain gains in terms of dynamic comparative advantages when a path of productivity growth is taking place. General support could be found, among others, in the learning mechanisms, production organization and product quality improvements. Second, a country's efforts to increase its participation with "new" commodities in the world market are mainly embodied in the changes in NIS-competencies addressed to support innovation and its diffusion.

\section{Figure 4 - NIS-competencies and trade growth performances: forging-ahead, catching up and falling-behind}

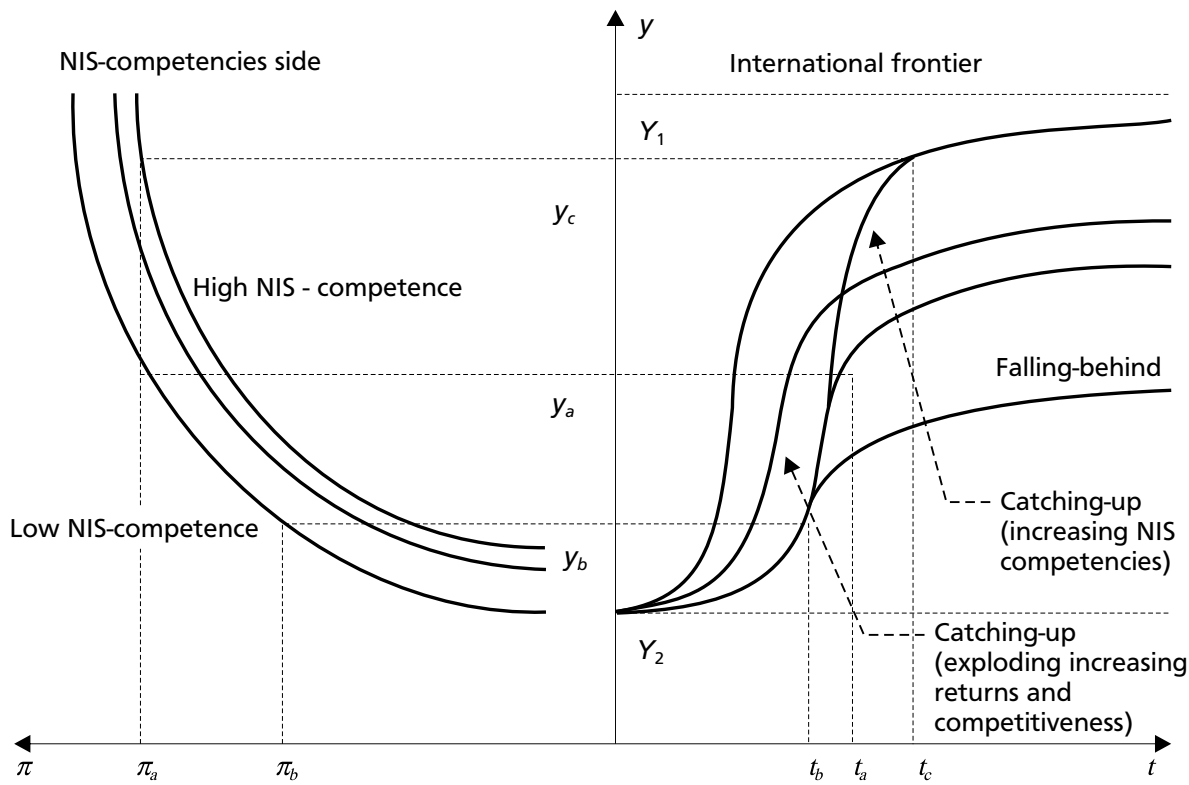

Source: Author's elaboration.

In Figure 4, the interplay between NIS-competencies and the catching up process is graphically represented. Looking at the left side, one can think of a "NIS-competencies frontier" which could be identified as the actual created asset that each economy has shown to build-up in order to support innovation and its diffusion ${ }^{15}$. Each $\pi-y$ schedule is build-up on a given NIS-competence. The figure tells us that an increase in

\footnotetext{
${ }^{15}$ From this point of view it clearly results that the NIS-competence assets is gaining an increasing importance in the explanation of comparative advantages and competitiveness. In a sense, it can be argued that the actual scenario seems to indicate that in an international context the importance of the "created assets" represented by the interplay between the NSI and the competences described before is growing (created versus natural assets).
} 
domestic productivity will lead to a higher domestic income (with respect the world economy). In other words, an export-led growth approach is here assumed ${ }^{16}$.

On the right side of the figure, the growth trajectories are displayed (whereas $y$ approximates the GDP as a proxy for the scope for catching-up). The export-led growth process is taking place on a single schedule relating $y$ changes over time. Thus, if our country is behind the international frontier, a process of catching-up is taking place when its productivity increase and learning mechanisms (associated to organizational changes, improved adaptation of imported capital goods and quality improvements, etc) in the production activities are obtained ${ }^{17}$. Two limits are represented when the catching-up path takes place, $(\mathrm{Y})_{1}$ and $(\mathrm{Y})_{2}$, which could be considered as physiological bottom-up of relative growth possibilities; in particular, $y_{1}$ represents the "international frontier" capturing the performance attained by the developed economies.

Again, on the left side, a successful effort to increase this NIS-competence asset would shift the schedule $\pi$-y upward. The same could be obtained when the set of institutions, which jointly and individually contribute to the development and diffusion of new technologies, improves the transfer and absorption capacity of knowledge flow and, consequently, the diffusion of the innovation process. Thus, an effort to increase NIS-competencies and improve their functionality would produce a jump of the schedule $y$ - $t$ reducing the gap from the international frontier.

In other words, a stronger effort to obtain a functional (well organized) NIS and higher competencies will lead to an upward shift in the schedules $\pi-y$ and $y$ (the income increase from $y_{\mathrm{a}}$ to $y_{\mathrm{c}}$ ). Thus, a higher participation and higher income with respect to the world economy could be reached; and a process of catching-up is taking place, reducing the growth gap in relation to the international frontier.

Most of the effects described before can be neutralized by a higher effort to increase the NIS-competence asset and improve its organization in the advanced countries. In this case, a jump of the international frontier $\left(\mathrm{y}_{1}\right)$ and an increasing gap in relation to the others growth trajectories could be obtained. A scenario of stable gap in the

\footnotetext{
${ }_{16}$ The size of the domestic market appears to be another crucial competitive factor. In a sense, it can be suggested that countries with a small domestic market are characterized by lower capabilities to develop economies of scale and technological spillovers. The domestic market and its size may have important implication when an effort in NIS-competences is made. In a sense, this effort can be neutralized if the economy has not yet reached the economies of scale required to support and gain in terms of international competitiveness. Moreover, if a larger country does a greater effort in NIS-competences, the lower cost of innovative activity and larger spillovers could explain international advantages. See Fagerberg (1995b).

${ }^{17}$ In this context, the introduction of dynamics increasing returns is assumed to explain the interplay between productivity and income.
} 
growth trajectories in terms of the international frontier could be viewed as the result of similar efforts in NSI-competencies.

The catching-up process introduced here puts its emphasis on differences in the scope of export-led growth and a country's potentiality to support the innovation system $^{18}$. In this sense, there are two mechanisms being introduced and described in Figure 4 . First, a country could exploit growing productivity on the basis of improved competitiveness and increased exports. This process is building-up on a given NIS-competency framework. Thus, learning mechanisms, organizational changes and quality improvements in production are the main sources of catching-up. Second, it can be stated that, since the catching-up process is shaped by the actual NIS-competencies, an effort to increase this asset and improve its functionality would make the country's growth trajectory jump near the international frontier.

The model sketched before accounts in a relatively straightforward manner for the following general property: that all efforts addressed to improve the functionality of the NIS-competencies - related to both institutions and resources - by a country could be viewed as a necessary condition to improve its economic performance. In the same sense one can see that a catching-up (or forging-ahead) growth trajectory is taking place. Conversely, a falling-behind trajectory is associated with a NIS-competence poorly organized and lower efforts to increase this asset.

Few examples of how the system functions are provided by the historical case studies discussed by Dosi, Pavitt and Soete (1990), showing the mechanisms through which the NIS, by fostering $\mathrm{R} \& \mathrm{D}$, has been enhancing the competencies of firms and industries, finally inducing an improvement in performances. The same type of relationship is also confirmed by the case studies recently conducted by OECD, that revealed the extent and types of collaborations between enterprises and the public sector research base (formal collaborations - such as commissioned research, joint R\&D projects, co-patenting and co-publications -, informal transaction - informal contacts and use of published scientific knowledge -, spin-offs from universities, and transfer of technology to enterprises - patents and product developments). At a more specific level, and in particular by focusing on the educational policy, another example of the relationship running through the NIS to enhanced competence and better performance is provided by the analysis of the Taiwanese experience supplied by Nelson (1993) and Della Giusta (1996).

In Germany, Japan and Sweden it has been often observed that, at least in most of the post-war period, the education and training systems have been particularly effi-

\footnotetext{
${ }_{18}$ Most of the works on catching-up put the emphasis on the scope for imitation (Gomulka, 1971; Abramovitz, 1979, 1994; and Maddison, 1991). The scope for imitation here is considered as a feature of both competitiveness - organizational and quality improvements - and NIS-competence efforts.
} 
cient in providing people with the requested standards in terms of knowledge and skills. University and government laboratories can therefore be considered as an important source for technological capabilities for the firms. In this respect, one can also mention the cases of Korea and Taiwan, emerging countries where it seems that education-led growth has contributed to shift international specialization from standard product to much more sophisticated ones, gradually characterized by a higher content of technological complexity.

In other words, a specialization increasingly oriented towards innovative commodities has been often supported and associated, particularly to the successful story cases, by long-term planning initiatives and public investments in "human capital". While, as a counterfactual example, in the case of Argentine and Brazil it seems that the weak links between the science and education systems and the industrial and R\&D systems contribute to explain their weak competitive performances. This institutional supportive environment reduces at least in part the serious analytical and empirical difficulties that scholars have faced in explaining within an incremental perspective the incredibly fast technological learning trajectories experienced by some Far Eastern firms (Freeman, 1987; Amsden, 1989; Canuto, 1994; Hobday, 1995).

Moreover, taking this analysis to its logical extreme, one might say that the international performance can be obtained only according to the differences in the NIS-competence displayed in each economy. Thus, international competition could be based on a "protected piece of the NIS-competencies", or on industries supported by government policies in terms of resources for the development of science and technology. That has been the case for Korean chaebols, as well as of the American computer, software and semiconductor industries, supported by research resources from the Department of Defense (Nelson, 1993; Genthon, 1995).

However, in this context, as it happens when one refers to the explanation of the interplay between science and innovation, even the relationship between NIS-competence and performance is neither linear nor deterministic in character.

In particular, when one thinks of other variables and relationships captured in the interplay between the specialization pattern and constraints imposed by trade balance conditions, the policies related to the macroeconomic setting and the exchange rate, some of the results presented herein could be modified and produce paradoxical scena$\operatorname{rios}^{19}$. Putting this observation into the above picture, one can identify different cases.

\footnotetext{
19 To some extent this approach has to be resembled introducing the kind of results obtained in the trade-growth analysis (from others, Dosi, Pavitt and Soete, 1990; Cimoli and Soete, 1992; Cimoli, 1994; Fagerberg, 1988, 1995a).
} 
For example, on the grounds of this context, the interplay that exists between dynamic endogenous changes of comparative advantages and national consumption patterns for the determination of differences in relative incomes and growth possibilities has been explicitly emphasized. National consumption patterns are determined by a mix average of income and price elasticities for a pattern of endogenously-determined specialization which are explicitly related to the constraints resulting from the external account.

By explicitly incorporating this analysis, a paradoxical result can be obtained associated to the perspective of falling behind or forging ahead as the technological learning and accumulation for the sectoral activities interact with the national consumption patterns, which are asymmetrical at a national level ${ }^{20}$. Think at the cases where specialization is mainly oriented to those sectors characterized by higher or lower rates of growth in world exports. Moreover, and as emphasized in much of the trade and development literature, the effect of the asymmetry on import demand is associated with the "type" and the income elasticities of the commodities produced and exported in both countries (one may think here of the case of primary and manufactured commodities or the different income elasticities associated to low and high tech products).

If a country shows high dynamics of increasing returns and learning capabilities in the sectors where the consumption pattern is not favorable, it may result in a process of falling behind. In the case of low dynamics of increasing returns and a favorable consumption pattern, a country may find a process of catching up or forging ahead. Thus, the possibility of forging ahead and catching-up are guaranteed when the learning capabilities are distributed in those activities associated to a favorable world consumption pattern.

In so far as distribution (changes in wages and productivities and wage-labor nexus prevailing in each economy) has also an impact on the trade performance, most of the NIS effect described above can be neutralized. Take an extreme analysis that in each country an oligopolistic (where the wage-labor nexus is characterized by tacit or statutory mechanisms of strong indexation of wages to labor productivity) or a classical form of regulation (where the wage-labor nexus is determined by a weak indexation of wage to productivity) prevails. Of course, in practice, these are two extreme archetypes, but most of the effects described above on the NIS-competence can be neutralized by the interaction of different dynamics in distribution variables which

\footnotetext{
${ }^{20}$ Thus, sectoral distribution of specialization can determine a divergence between the production and consumption pattern at national level. In this context, as introduced in Pasinetti (1981), the asymmetry in the domestic and foreign consumption patterns is considered a key element in the explanation of the convergence versus divergence in the output rate of growth.
} 
could move in favor or to the detriment of the domestic country ${ }^{21}$. What emerges, in other words, is that the traditional income growth effects due to relative changes in prices and wages and differences in the demand structure are not so clear (let alone obvious). Thus this situation can clearly lead to situations where the celebrated case of immiserizing growth and Prebisch-Singer thesis could prevail.

Another aspect that could clearly neutralize the effects of NIS-competencies relates to the cases where the macroeconomic setting is characterized by the high instability frequently emerging from the vicious circle of depreciation-appreciation of the exchange rate. This scenario characterizes most of the semi-industrialized economies in Latin America (Argentina, Brazil and Mexico), and, particularly, the main economic actors involved in the process of acquisition and diffusion of innovation do not take any decision involving a long term perspective because their strategies are take care, wait and see how the exchange rate will move. In a sense, efforts oriented to the increasing on NIS-competencies could be neutralized by a macro-setting characterized by high instability.

However, when a stable macroeconomic setting prevails, the delinking of the exchange rate from the real economy (trade and specialization) is concerned with the existing differences in NIS-competencies and its evolution over time. A high delinking is related to large differences in the NIS-competence. A similar case emerges when dedicated efforts arise in the leader innovating countries and a process of forging ahead or falling behind is taking place; conversely, a large sensitivity occurs when countries are characterized by small differences in this created asset and a process of catching-up is resulting. In a sense, what paradoxically takes place is that the actual effects of the exchange rate on trade flows and specialization are closely linked, given a stable macroeconomic setting, to the differences in NIS-competence assets.

\section{CONCLUSIONS}

The purpose of this paper was to discuss the empirical and analytical features that support NIS analysis for the understanding of its implication on the sources of technological asymmetries and growth, which show different performances across countries.

The importance of the institutional dimension for the understanding of technological asymmetries should come as no surprise, supported by growing evidence from

\footnotetext{
21 These empirical archetypes of the institutions governing the labor market are extensively analyzed in the theory of regulation developed in Boyer (1988a, 1988b).
} 
the neo-Schumpeterian trade and growth approaches. After all, at the micro level, technologies are to a fair extent incorporated into particular institutions, the firms, whose characteristics, decision rules, capabilities, and behaviors are fundamental to shaping the rates and directions of technological advance. In turn, firms are embedded in rich networks of relations with each other and with other institutional actors - ranging from government agencies to universities etc. Moreover, a major element linking microeconomic learning with national patterns of development is the embeddedness of the thread of incentives, constraints, and types of corporate organization into the broader institutional framework of the political economy of each country.

The NIS could be considered as a useful concept that captures the countries asymmetries in institutions, linkages, sectoral patterns of diffusion and production of innovation. Moreover, we would like to push this point to a more economic view of the NIS where the linkages with country's growth performances should be internalized. Two are the main reasons supporting this view.

First, we asserted that the NIS view could increase its significance when its meaningful will is addressed to recover some economic patterns regarding specificities of the economies interested in a catching-up process. Examples, among others, include the strategies to promote industrialization (export-led growth versus inward-oriented strategies) and technological capabilities (building-up a consistent NIS with increasing effort to improve its functionality), the main features of macroeconomic setting, the exchange rate policy and the actual specialization. Moreover, export-led growth mechanisms, based on learning and organizational changes in the production activities, and stronger effort to obtain a functional (well organized) NIS and higher competencies will lead to an upward shift of the growth trajectory and a catching-up process.

Second, the emphasis on the NIS and its interplay with trade-growth approaches tends to up-play the understanding that can be made around further empirical works and appreciative theorizing on this topic. Going back to the particular type of NIS representation introduced here, it is very important to underline that this representation is oriented to capture the functional relationships among variables, and it is essentially to the estimation and description of these relationships, rather than to that of the coefficients of the individual variables involved, that attention should be devoted. The idea is related to the identification of specific linkages that relate macro-setting, institutions, competencies and performances applying to different methodological analyses, which move from the evidence contained in the historical case studies to the graphical exercises introduced in the previous sections. It is important to bear in mind that within this context the representation proposed here can be considered as an experimental approach, where the relationships of a certain kind between technical change and economic performance are being analyzed from a different perspective. 
Thus, for example, on the one hand, the intuitive hypothesis that improvements in the efficiency of techniques of production or in product performances may be a determinant, or at least a binding precondition, of growth in per capita income and consumption should be more extensively investigated. On the other hand, in a dynamic perspective, we can introduce the debate about the question on whether institutions and competencies supporting technical change are sufficiently adaptive to adjust to whatever underlying economic change emerges from market interactions, or conversely, whether they are inertial enough to shape the rate of direction of innovation and economic performance. In a broad sense, the idea proposed here is aimed at maintaining the concept of NIS anchored at a "macro-technological and institutional" container which enables an evaluation of innovative efforts and economic performance.

\section{REFERENCES}

ABRAMOVITZ, M. "Rapid growth potential and its realisation: the experience of capitalist economies in the postwar period". In: MALINVAUD, E. (Ed.) Economic growth and resources: the major issues. London: Macmillan, 1979.

ABRAMOVITZ, M. "The origins of the postwar catch-up and convergence boom". In: FAGERBERG, J.; VON TUNZELMAN, N.; VERSPAGEN, B. (Eds.) The dynamics of technology, trade and growth. London: Edward Elgar, 1994.

AMABLE, B. Effects d’apprentissage, compétitivité, hors-prix et croissance cumulative. Economie Appliquée, v. 45, p. 5-31, 1992.

AMABLE, B. "National effects of learning international specialization and growth paths". In: FORAY, D.; FREEMAN, C. (Eds.) Technology and the Wealth of Nations. London: Pinter Publishers, 1993.

AMSDEN, A. Asia's next giant: South Korea and late industrialization. New York: Oxford University Press, 1989.

ARTHUR, W. B. Competing technologies, increasing returns and lock-in by historical events. Economic Journal, v. 99, n.1, 1989.

BARDHAN, P. The political economy of development policy: an Asian perspective. In: Development Thinking and Practice Conference, Washington, D. C., Sept. 3-5, 1996.

BOGGIO, L. Growth and international competitveness in a Kaldorian perspective. Milano: Università Cattolica del Sacro Cuore, Istituto di Teoria Economica e Metodi Quantitativi, 1993, mimeo.

BOYER R. “Technical change and the theory of regulation”. In: DOSI, G.; FREEMAN, C.; NELSON, R.; SOETE, L. (Eds.) Technical change and economic theory. London: Frances Pinter, 1988a.

BOYER, R. "Formalizing growth regimes within a regulation approach" In: DOSI, G.; FREEMAN, C.; NELSON, R.; SOETE, L. (Eds.) Technical change and economic theory. London: Frances Pinter, 1988b. 
CANUTO, O. Brasil e Coréia do Sul: os (des)caminhos da industrialização tardia. São Paulo: Nobel, 1994.

CANTER, U.; HANUSCH, H. Process and product innovation in an international trade context. In: EAEPE Conference, 2, Florence, Nov. 15-17, 1990.

CANTWELL, A. J. "The theory of technological competence and its application to international production”. In: MCFETRIDGE, D. G. (Ed.) Foreign investment, technology and growth. Calgary: University of Calgary Press, 1991.

CARACOSTAS, P.; SOETE, L. “The building of cross-border institutions in Europe: Towards a European System of Innovation?”. In: EDQUIST, C. (Ed.) Systems of Innovation. London: Francis Pinter, 1997.

CIMOLI, M. "Look-in and specialization (dis)advantages in a structuralist model with endogenous growth". In: FAGERBERG, J.; VON TUNZELMAN, N.; VERSPAGEN, B. (Eds.) The dynamics of technology, trade and growth. London: Edward Elgar, 1994.

CIMOLI, M. Technological gaps and institutional asymmetries in a North-South model with a continuum of goods. Metroeconomica, v. 39, p. 245-274, 1988.

CIMOLI, M.; SOETE, L. A generalized technological gap trade model. Economie Appliquée, v. 45, p. 33-54, 1992.

CIMOLI, M.; DOSI, G. Technological paradigms, patterns of learning and development: an introductory roadmap. Journal of Evolutionary Economics, v. 5, n. 3, 1995.

CIMOLI, M.; DELLA GIUSTA, M. The nature of technical change and its main implication on national and local systems of innovation. IIASA Interim Report IR-98-029, 1998.

DELAPIERRE, M.; ZIMMERMANN, J. B. L'informatique du nord au sud, un complexe industriel transnationalisé. Paris: La Documentation Française, 1986.

DELLA GIUSTA, M. Education and technological capabilities in industrialization. Master's Thesis, University of Reading, 1996.

DOLLAR, D. “Technological innovation, capital mobility, and the product cycle in the North-South model. American Economic Review, n. 76, p. 177-190, 1986.

DOSI, G. Technical change and industrial transformation. London and New York: MacMillan, 1984.

DOSI, G.; SOETE, L. Technological gaps and cost-based adjustment: some explorations on the determinants of international competitiveness. Metroeconomica, n. 12, p. 357-382, 1983

DOSI, G.; SOETE, L. “Technical change and international trade”. In: DOSI, G.; FREEMAN, C.; NELSON, R.; SOETE, L. (Eds.) Technical change and economic theory. London: Frances Pinter, 1988, p. 401-431.

DOSI, G.; FREEMAN, C. The diversity of development patterns: on the processes of catching-up, forging ahead and falling behind. In: Conference on Economic Growth and the Structure of Long-term Development, Varenna, Oct. 1-3, 1992.

DOSI, G.; PAVITT, K.; SOETE, L. The economics of technical change and international trade. London and New York: Harvester Wheatsheaf Press and New York University Press, 1990.

DOSI, G.; NELSON, R. Evolutionary theories in economics: assessment and prospects. IIASA Working Paper, WP-93-064, Nov. 1993. 
EDQUIST, C. (Ed.) Systems of Innovation. London: Francis Pinter, 1997.

FAGERBERG, J. International competitiveness. Economic Journal, n. 98, p. 355-374, 1988.

FAGERBERG, J. Convergence or divergence? The impact of technology on "why growth rates differ". Journal of Evolutionary Economics, v. 5, n. 3, 1995a.

FAGERBERG, J. Is there a large-country advantage in high-tech? NUPI Working Papers, n. 526, $1995 \mathrm{~b}$.

FREEMAN, C. The plastic industry: a comparative study of research and innovation. National Institute Economic Review, n. 26, p. 22-62, 1963.

FREEMAN, C. Technology policy and economic performance: lessons from Japan. London: Francis Pinter, 1987.

GAIO, F. J. The development of computer software technological capabilities in developing countries. A case study of Brazil. Ph. D. Thesis, SPRU, Brighton, 1990.

GENTHON, C. Croissance et crise de l'industrie informatique mondiale. Paris: Syros, 1995.

GRANOVETTER, M. Economic action and social structure: the problem of embeddedness. American Journal of Sociology, n. 91, p. 481-510, 1985.

GOMULKA, S. Inventive activity, diffusion and the stages of economic growth. Aarthus: Institute of Economics and Aarthus University Press, 1971.

HIRSCH, S. The US electronics industry in International trade. National Institutte Economic Rewie, n. 34, 1965.

HOBDAY, M. Innovation in East Asia. Cheltenham: Edward Elgar, 1995.

HUFBAUER G. Syntetic materials and the theory of international trade. London: Buckworth, 1966.

KATZ, J. Structural reforms, the sources and nature of technical change and the functioning of the national systems of innovation. The case of Latin America Case. In: International Symposium On Innovation and Competitiveness in NIEs, Seul, Korea, May 1997.

KIM, L. Korea's national innovation system in transition. In: International Symposium on Innovation and Competitiveness in NIEs, Seul, Korea, May 1997.

KRUGMAN, P. The narrow moving band, the Dutch disease and the competitive consequences of the Mrs Thatcher. Journal of Development Economics, v. 27, p. 41-55, 1987.

LALL, S. Technological change and industrialisation in the Asian NIEs: achievements and challenges. In: International Symposium on Innovation and Competitiveness in NIEs, Seul, Korea, May 1997.

LUNDVALL, B. National Systems of Innovation: towards a theory of innovation and interactive learning. London: Francis Pinter, 1993.

MADDISON, A. Dynamics forces in capitalist development. New York: Oxford University Press, 1991.

METCALFE, S. “Trade, technology and evolutionary change”. In: HARRINGTON, R. et al. (Eds.) Money, trade and payments. Manchester, UK: Manchester University Press, 1989, p. 210-234.

METCALFE, S. "The economic foundations of technology policy”. In: STONEMAN, P. (Ed.) Handbook of the Economics of Innovation and Technical Change. Oxford: Blackwell, 1995. 
METCALFE, S.; SOETE, L. "Notes on the evolution of technology and international competition”. In: GIBBONS, M. ET AL. (Eds.) Science and Technology Policy in the 1980's and Beyond. London: Longman, 1984.

MISA, T. J. Constructive technology assessment: cases, concepts, conceptualization. In: Conference on Constructive Technology Assessment, 20, The Netherlands, Sept. 1991.

NELSON, R. (Ed.) National Systems of Innovation. Oxford: Oxford University Press, 1993.

PASINETTI, L. Structural change and economic growth. Cambridge: Cambridge University Press, 1981.

POSNER, M. V. International trade and technological change. Oxford Economic paper, n. 13, p. 323-341, 1961.

SOETE, L.; VERSPAGEN, B. Competing for growth: the dynamics of technology gaps. convergence and imovation. In: Conference on Economic Growth and the Structure of Long-term Development, Varenna, 1-3 Oct., 1992.

VERNON, R. International investment and international trade in product cycle. Quarterly Journal of Economics, n. 80, p. 190-207, 1966.

VERSPAGEN, B. Catching up or falling behind? A dynamic model of growth rate differential. Merit Research Memorandum, n. 90-004, 1990.

VERSPAGEN, B. Technology, specialization patterns and growth rate differential: a multi-sector evolutionary model of balance of payments restricted growth. Merit research Memorandum, n. 91-007, 1991.

WADE, R. Governing the market: economic theory and the role of government in East Asian industrialization. New Jersey: Princeton University Press, Princeton, 1990.

WEIL, S. L'enracinement. Prélude à une déclaration des devoirs envers lêtre humain. Paris: Gallimard, 1949.

ZYSMAN, J. How institutions create historically rooted trajectories of growth. Industrial and Corporate Change, n. 3, p.243-283, 1994. 